\title{
液状化地盤の沈下を受ける地中管路の挙動に関する研究 BEHAVIOR OF BURIED PIPELINES SUBJECTED TO GROUND SETTLEMENT DUE TO LIQUEFACTION
}

\author{
高田至郎*·片桐 信**·孫 建生*** • 山下淳志**** \\ By Shiro TAKADA, Shin KATAGIRI, Jian Sheng SUN and Atsushi YAMASHITA
}

\begin{abstract}
In this paper, we, first, obtained resistance and spring constants acting on buried pipelines when subjected to ground settlement due to liquefaction by an experiment of lifting up pipes in liquefied ground. Second, we investigated the suitability of the spring constants by comparison of the result by a different experiment using a dual sinking soil box with results of non-linear analyses using transfer matrix method. Furthermore, we proposed design formulae and equivalent spring constants of the liquefied ground. The formulae were obtained by beam theory on an elastic foundation and the equivalent spring constants were determined such that calculated values of pipe responses by the proposed formulae are well matched with the result of non-linear analyses.
\end{abstract}

Keywords : pipelines, liquefaction, ground settlement, elastic foundation, spring constants

\section{1.はじめに}

緩い砂の液状化地盤では土粒子の側方移動, 間隙水圧 の消散に伴う圧密によって, 地震後に著しい不等沈下が 発生する. 既存の調査資料によれば盛土地盤の最大沈下 量は $4 \mathrm{~m}$ 以上に, 平地地盤の最大沈下量は $1 \mathrm{~m}$ 以上に 達する場合があり ${ }^{11}$, 非液状化地盤の地震時沈下量の数 倍となっている.

1983 年日本海中部地震時に八竜町の浜口地区では砂 質地盤における噴砂現象がいたるところでみられた. 道

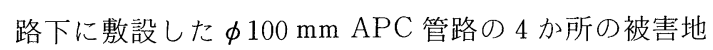
点ではいずれも5～20 cm の垂直変位が生じており,こ れは液状化地盤の不等沈下に伴う管路被害である21. 能 代市松広町から西通町にかけての道路の地下数 $\mathrm{m}$ まで はきわめて液状化しやすい粒径分布の砂で, 地震時の隆 起, 沈下により, $300 \mathrm{~m}$ 範囲内の道路下の水道, ガス, 通信, 下水道管路で延べ 100 か所の被害が発生している.

* 正会員 工博 神戸大学助教授 工学部土木工学科 ( (657 神戸市灘区六甲台町)

** 正会員 工修 久保田鉄工 (株) 合成管研究部 ( (592 堺市石津西町 14-2 番地)

*** 学生会員 工修 神戸大学大学院自然科学研究科 ( 干657 神戸市灘区六甲台町)

**** 学生会員 神戸大学大学院工学研究科 (同上)
被害の発生箇所は道路の沈下, 隆起箇所とよく一致して おり, 液状化地盤の不等沈下による被害と推察できる ${ }^{21}$. また，他の地震でも同様の被害報告がある.

高田らは日本海中部地震の際の液状化被害を受けた通 信管路の詳細調査によって相対的にマンホールは浮上し 管路は沈下して, マンホールとの取り付け部とその付近 の管路に応力集中が発生し, 管路が被害を受けることを 明らかにしだ!.

液状化地盤での震動, 浮力を受ける地中管路の挙動実 験 $^{41,5)}$ および非液状化地盤の沈下による地中管路挙動実 験61,71は多く報告されているが, 液状化地盤での沈下を 受ける管路の挙動の実験の報告はほとんどない.

地震波動を受ける管路挙動を検討するのに用いられる 地盤ばね定数とその解析方法は種々に提案されてい $ろ^{81}$. また, 田邊らは軟弱地盤沈下を受ける管路のいく つかのケースについて設計式を提案して, さらに, 実験 結果との比較によって設計式の有効性および設計用の等 価ばね定数を検討している ${ }^{9 !}$.

本文では, 地震時に液状化地盤沈下を受ける地中管路 の設計を行う観点から, 地中管路を含んだ地盤が液状化 した場合 (管路周囲は液状化層), 地中管路を含んだ層 が液状化せずにその下層部分が液状化して沈下あるいは 側方流動することにより地中管路位置が沈下する場合 
で, 地下水位面が地中管路より下にある場合（管路周囲 は排水砂層）および地下水位面が地中管路の上にある場 合（管路周囲は飽和砂層）の 3 ケースに対して液状化地 盤沈下が地中管路に及ぼす力の算定および地中管路挙動 を把握する設計式の提案を試みている.

\section{2. 地中管路に作用する地盤力実験}

液状化地盤が不等沈下するときに，管路と地盤とは相 対変位を発生するが, 室内実験で液状化地盤中の管路を 上方に持ち上げ，地盤と相対変位を発生する方法で液状 化地盤, 排水砂地盤中の管路の上方抵抗実験を実施し, 液状化沈下を受ける管路に作用する地盤力を把握する.

\section{（1）液状化地盤中の管路の上方抵抗実験}

図一1に実験の概要を示している，振動台上のせん断 砂槽内に管路を埋設している. 管路の 2 か所にワイヤ ロープを取り付け，それをI 形鋼，ロードセルを介して クレーンで引き上げて測定を行った。

地盤が完全液状化したのち管路をクレーンで引き上 げ，そのときの変位と抵抗力をそれぞれ変位計とロード セルにより計測した. 地盤の完全液状化は地盤中に設置 した水圧計 $\left(\mathrm{P}_{2}, \mathrm{P}_{3}, \mathrm{P}_{4}\right)$ および加速度計 $\left(\mathrm{A}_{2}\right)$ によっ て判断した。また測定は振動中に管路を引き上げる場合 と, 振動停止直後に管路を引き上げる場合の 2 種類を 行った．液状化中の地盤ば站定数は振動中に引き上げる 実験により,また液状化終了直後の地盤ばね定数は振動 停止直後に引き上げる実験により検討した.

実地盤の地震時せん断変形現象を再現するために, 幅 ×長さメ高さが $75 \mathrm{~cm} \times 240 \mathrm{~cm} \times 100 \mathrm{~cm}$ のせん断砂槽 を使っており，せん断槽は軽量の FRP 製のフレーム 10 層からなっている. 各層間はボールベアリングで支 持されて任意の水平方向に $1 \mathrm{~cm}$ ずつ動くことができる

(図一2参照).これにより砂層のせん断変形の拘束の 影響を軽減させている，さらに最下層には金網と砂で上 部地盤と仕切られた水槽を設け, その中の配管から水を

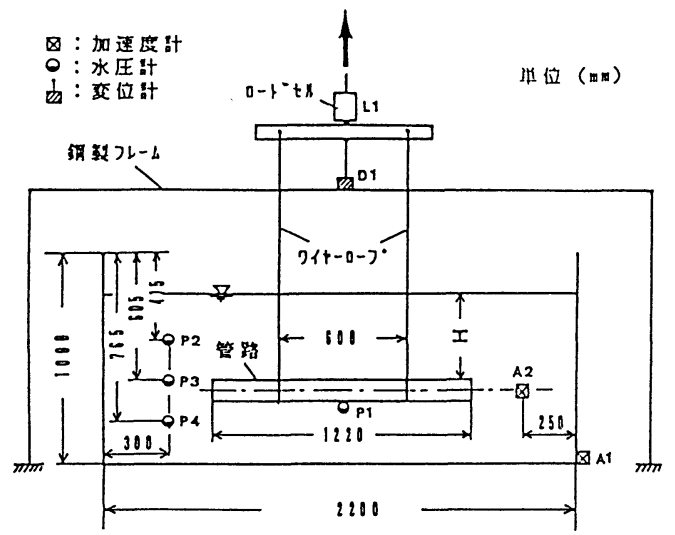

図一1 液状化地盤中の管路上方抵抗実験概要図

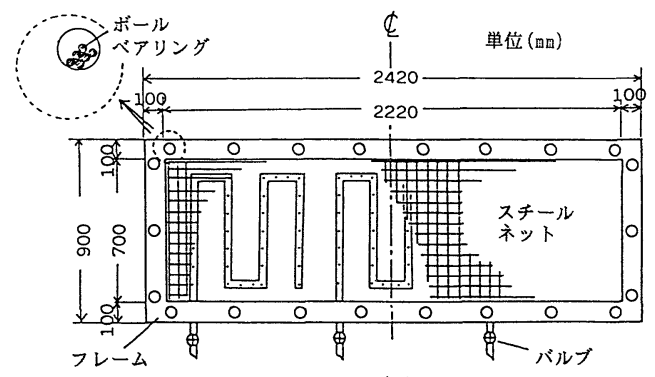

(a) 平面図

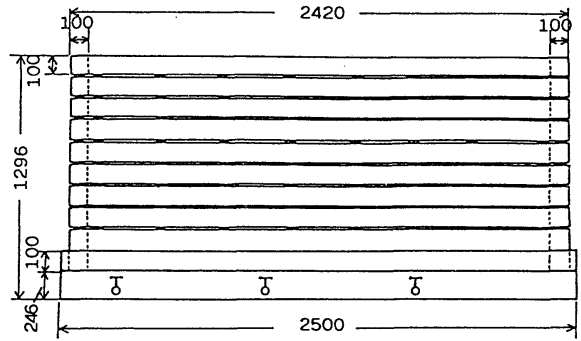

(b) 側面図

図一2 せん断变形砂槽の概要図

吹き上げることにより緩詰めの均質地盤が再現できるよ うに工夫している.

模型地盤材料は粒径を調整した液状化しやすい砂 ${ }^{010} を$ 使用している. 飽和砂のコアサンプリングが困難なこと， 本実験の目的が液状化した地盤の抵抗力測定であること を考慮して，模型地盤の密度実験は行っていない.

入力波としては加速度が $200 \mathrm{gal}$, 振動数は模型地盤 が液状化しやすい $5 \mathrm{~Hz}$ の正弦波を用いた。埋設管路は $\phi 48 \mathrm{~mm}$ および $\phi 102 \mathrm{~mm} の 2$ 種類の鋼管路を使用し た. 長さはそれぞれ $120.4 \mathrm{~cm}, 122.0 \mathrm{~cm}$ である. また， 引き上げに伴う変形が無視できるように剛性の高い鋼管

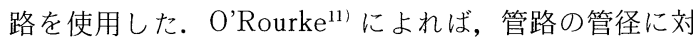
して長さが 10 倍以上あればパイプの側面の影響は無視 できる、本実験で使用する 2 本の管路はともにこの条件 を満たしており，側面の影響は無視できるものとした. 図一1に示されるように管路の引き上げ力，変位は口一 ドセル $\mathrm{L}_{1}$ と変位計 $\mathrm{D}_{1}$ で測定し, 地盤の応答は土層に 設置している間隙水圧計 $\mathrm{P}_{2}, \mathrm{P}_{3}, \mathrm{P}_{4}$, 加速度計 $\mathrm{A}_{2}$ で測 定し, 振動台の入力加速度は加速度計 $A_{1}$ で測定してい る. 土中加速度計 $\left(A_{2}\right)$ によれば液状化した模型地盤 の振動加速度がごく小さい(10)ため，振動中に管路を引き 上げる場合の地盤振動による動的影響は無視した。

\section{（2）排水砂および飽和砂に対する管路の上方抵抗実 験}

実験の概要を図一3に示している. $\phi 102 \mathrm{~mm}$ および $\phi 48 \mathrm{~mm}$ の鋼製管路をボルトで固定したうえで模型砂槽 に埋設し, 砂槽上部に取り付けた油圧ジャッキにより上 方に引き上げている. そのときの抵抗力はジャッキに連 
動したロードセルにより，また変位は砂槽側壁に取り付

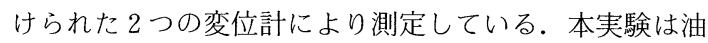
圧ジャッキで変位を与えているため, 管路の引き上げは 段階的になり変位と抵抗力が一定值に落ち着いた後（約 15 分程度）に引き上げた。飽和砂模型地盤は緩詰めに 作成した砂地盤に上部からホースを差し入れ給水し, 地 盤全体が均一な飽和状態になるようにした。 また，排水 砂地盤はいったん飽和させた地盤を作成し, その後砂槽 底部に取り付けたバルブから排水したものを用いた。

\section{(3) 実験結果}

上記実験で得られたデータを表一1に，また液状化実 験において, 管路に作用する土の抵抗力-変位関係を図 -4(a), (b) に, 飽和砂, 排水砂地盤実験における抵抗 力-変位関係を図-4(c), (d) に示している. 図一4の 縦軸は抵抗力を無次元化した值 $\left(F /\left(\gamma \cdot H^{\prime} \cdot D \cdot L\right), F\right.$ : 抵抗力, $\gamma$ : 砂地盤の単位体積重量, $H^{\prime}$ : 地表面から管 路中央部までの深さ, $D$ : 管路の直径, $L$ : 管路の長さ), 横軸は変位を無次元化した值 $\left(\delta_{V} / D, \delta_{V}\right.$ : 鉛直方向変位 $)$ である。

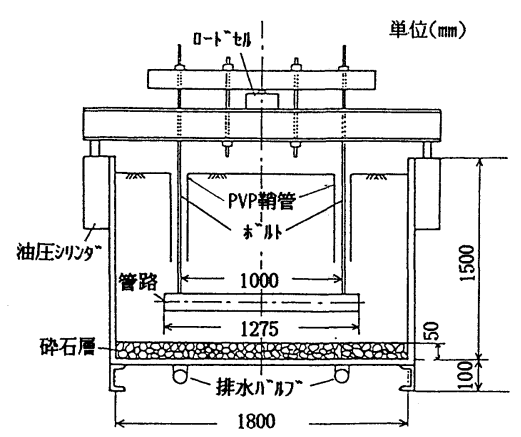

図一3 排水砂・飽和砂地盤中の管路上方抵抗実験概要図

\section{表一1 実験結果の概要}

\begin{tabular}{|c|c|c|c|c|c|c|}
\hline 実稌名 & 祀号 & $\begin{array}{l}\text { 管径 } \\
D(\mathrm{~mm})\end{array}$ & $\begin{array}{c}r \\
\left(\mathrm{KN} / \mathrm{cm}^{3}\right)\end{array}$ & $H^{\prime} / 0$ & $\frac{F_{B B}}{r \cdot D \cdot L \cdot H^{\prime}}$ & $\begin{array}{c}8 \mathrm{v}, \mathrm{cri} \\
\text { (cai) }\end{array}$ \\
\hline $\begin{array}{c}\text { 液状化中 } \\
\text { 英 }\end{array}$ & $\begin{array}{l}\text { V1 } \\
\text { V2 } \\
\text { V3 } \\
\text { v4 } \\
\text { v5 } \\
\text { v6 }\end{array}$ & $\begin{array}{r}102 \\
102 \\
102 \\
102 \\
48 \\
48\end{array}$ & $\begin{array}{l}19.8 \\
19.8 \\
19.8 \\
19.8 \\
19.8 \\
19.8\end{array}$ & $\begin{array}{l}4.52 \\
3.44 \\
2.17 \\
4.23 \\
9.54 \\
6.42\end{array}$ & $\begin{array}{l}3.05 \\
3.24 \\
5.00 \\
3.75 \\
3.99 \\
3.87\end{array}$ & $\begin{array}{l}4.25 \\
4.58 \\
3.65 \\
5.00 \\
7.91 \\
6.64\end{array}$ \\
\hline 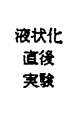 & $\begin{array}{l}\text { VA1 } \\
\text { VA2 } \\
\text { VA3 } \\
\text { VA4 } \\
\text { VA5 } \\
\text { VA6 }\end{array}$ & $\begin{array}{r}102 \\
102 \\
102 \\
102 \\
48 \\
48\end{array}$ & $\begin{array}{l}19.8 \\
19.8 \\
19.8 \\
19.8 \\
19.8 \\
19.8\end{array}$ & $\begin{array}{r}4.96 \\
3.69 \\
2.41 \\
13.52 \\
9.69 \\
6.63\end{array}$ & $\begin{array}{l}3.99 \\
3.57 \\
4.82 \\
3.07 \\
2.32 \\
4.37\end{array}$ & $\begin{array}{r}5.45 \\
3.83 \\
2.91 \\
14.77 \\
17.93 \\
7.62\end{array}$ \\
\hline 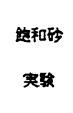 & $\begin{array}{l}\text { W1 } \\
\text { Y2 } \\
\text { W3 } \\
\text { Y4 } \\
\text { U5 }\end{array}$ & $\begin{array}{r}48 \\
102 \\
102 \\
102 \\
165\end{array}$ & $\begin{array}{l}19.8 \\
19.8 \\
19.8 \\
19.8 \\
19.8\end{array}$ & $\begin{array}{l}21.3 \\
10.8 \\
10.7 \\
4.62 \\
5.83\end{array}$ & $\begin{array}{l}1.47 \\
1.52 \\
1.05 \\
1.03 \\
0.78\end{array}$ & $\begin{array}{l}3.00 \\
2.45 \\
2.79 \\
2.80 \\
2.00\end{array}$ \\
\hline 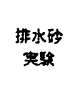 & $\begin{array}{l}01 \\
02 \\
03 \\
04\end{array}$ & $\begin{array}{r}48 \\
102 \\
102 \\
165\end{array}$ & $\begin{array}{l}19.8 \\
19.8 \\
19.8 \\
19.8\end{array}$ & $\begin{array}{l}22.8 \\
10.3 \\
5.29 \\
6.95\end{array}$ & $\begin{array}{l}6.90 \\
4.75 \\
4.46 \\
3.19\end{array}$ & $\begin{array}{l}3.60 \\
4.20 \\
1.50 \\
1.50\end{array}$ \\
\hline
\end{tabular}

図一4に示すように排水砂・飽和砂地盤では無次元化 最大抵抗力の最大值は $H^{\prime} / D$ (地表面から管路中央部ま での深さと管路直径の比）の無次元化量が大きくなるほ よ゙高い値を示しているが, 液状化中・終了直後の結果は そのような顕著な傾向はみられなかった.さらに, 無次 元化抵抗力の最大值以後は, 液状化中 - 終了直後地盤で は抵抗力が急激に低下しているが, 他の排水砂, 飽和砂 実験ではその低下率が小さい. 図一5 は各実験結果につ いて, さらに埋設深さ $H^{\prime}$ と最大抵抗力 $F_{m}$ の関係をみ るために無次元化最大抵抗力 $\left(F_{m} / \gamma \cdot h \cdot D \cdot L\right)$ と $H^{\prime} / h$ の関係を示している. $h$ は地盤厚さである. なお, 最大 抵抗力はその最大值, または変位の増加に対して抵抗力

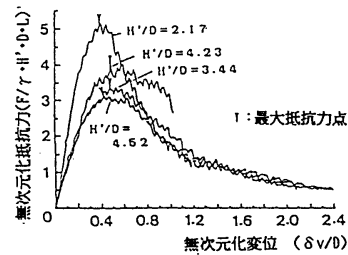

（8）楛状化中

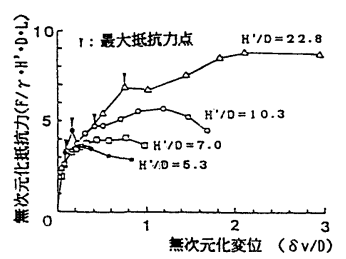

(c) 排水的

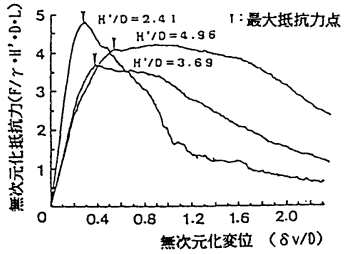

(b) 液犾化㨁琕

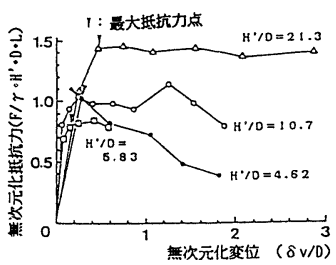

(d) 路和蠤
図-4 無次元化抵抗力-変位関係
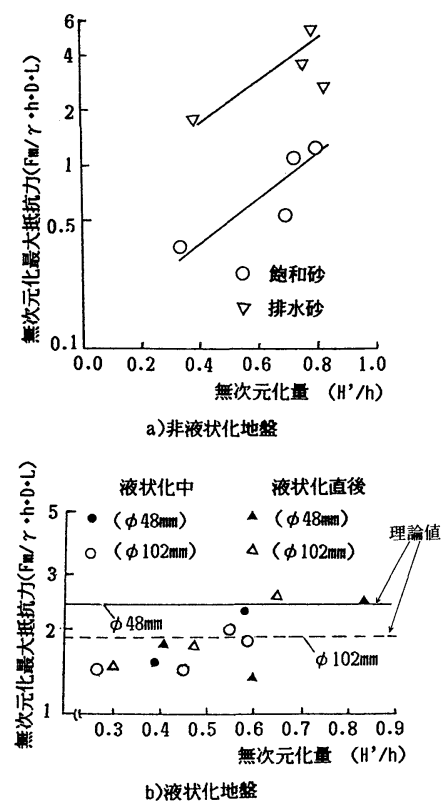

図一 5 無次元化抵抗力と $H^{\prime} / \boldsymbol{h}$ の関係 
の増加率が急激に低下している点をもって定めている. 限界変位は最大抵抗力と対応する変位とする．飽和砂 · 排水砂の場合に管路埋設深さ無次元量 $H^{\prime} / h$ が大きくな るほど無次元最大抵抗力 $\left(F_{m} / \gamma \cdot h \cdot D \cdot L\right)$ が大きくなる. 液状化地盤の場合にはこの傾向が明確ではない.

一方，永井らは液状化地盤を粘性流体ととらえ，小球 が液状化地盤を沈降していく際の速度を測定することに よって地盤の粘性係数を求めた. その結果, 液状化地盤 は粘性係数が $2 \sim 6 \mathrm{~g} \cdot \mathrm{s} / \mathrm{cm}^{2}$ の粘性流体と考えてさしつ かえないとしている ${ }^{12)}$. そこで，管状の構造物を横切る 粘性流体の流れによる単位長さ当たりの力 $F_{c}$ について はLagerstrom ら ${ }^{13)}$ の提案した理論式（1）を使って液 状化中・終了直後地盤での埋設管路に作用する抵抗力を 求めると以下のようになる.

$$
F_{c}=48.98 \cdot \pi \cdot \mu \cdot w_{0} /[0.5-\ln (209.96 \cdot R e)]
$$

ここに, $\mu$ : 粘性係数, $w_{0}$ : 相対速度, $R e$ : レイノル ズ数 $\left(R e=w_{0} \cdot D / \nu, \nu\right.$ : 動粘性係数 $)$.

いま, 液状化中 ・ 終了直後の地盤の粘性係数を 3.8 $\mathrm{g} \cdot \mathrm{s} / \mathrm{cm}^{2}$ とすると $\phi 48 \mathrm{~mm}$ の場合は $F_{c}=206 \mathrm{kgf}, \phi 102$ $\mathrm{mm}$ の場合は $F_{c}=364 \mathrm{kgf}$ となり, 図一5(b) に示すよ

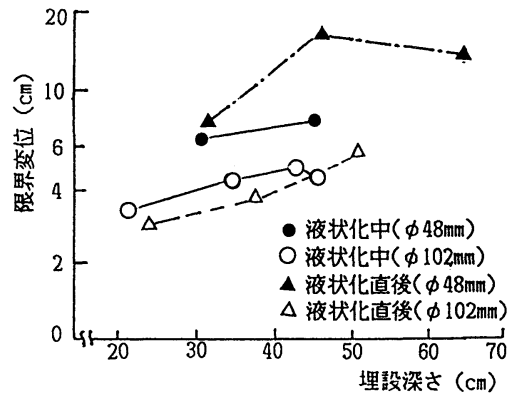

図一6 限界変位と埋設深さの関係

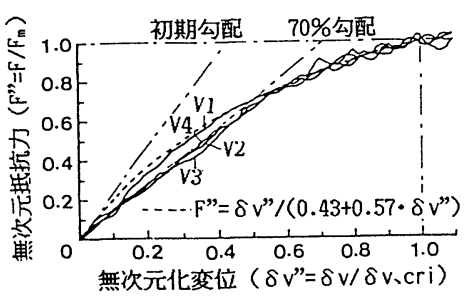

a) 液状化中

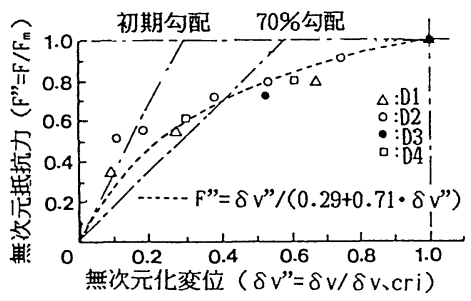

c) 排水砂

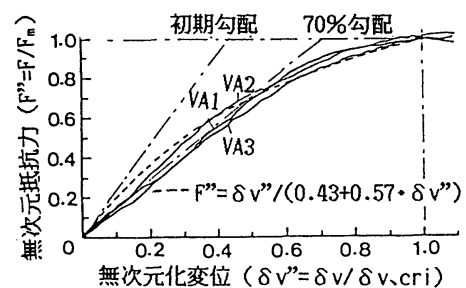

b)液状化直後

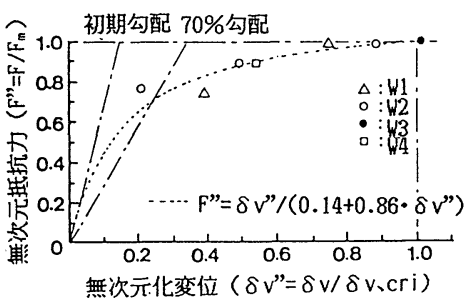

d) 蚫和矿
図一7 無次元化抵抗力-変位関係（双曲線関数表示）
うに,これらの值を実験結果と比較すると, 両ケースと もに埋設深さが大きい付近では実験結果とよく対応して いる. しかし，埋設深さが小さくなるに従って実験結果 は計算値より小さくなる傾向がある.その原因として上 述の式（1）は一様の流れの中に置かれた管状構造物の 抵抗力を求めており，埋設深さが小さいと地表面の影響 が大きく作用するため差異が出てくると考えられる.つ まり，液状化地盤では埋設深さが大きい場合は粘性流体 的性格が卓越しているが，埋設深さが小さくなるに従つ て地表面の影響が大きくなり，粘性流体的性格が薄れて いると思われる。

図一 6 は, 液状化地盤の最大上方地盤抵抗力を示すと きの変位量 (以下, $\delta_{V, \mathrm{cri}}$ : 限界変位と略す) と埋設深 さ $H^{\prime}$ の関係を示している. 図より, 液状化終了直後地 盤では埋設深さが大きくなるに従い, 限界変位も大きく なる傾向にあるが，液状化中地盤ではほぼ一定値をとっ ており,限界変位の平均值は $\phi 48 \mathrm{~mm}$ の場合は $7.28 \mathrm{~cm}$, $\phi 102 \mathrm{~mm}$ の場合は $4.37 \mathrm{~cm}$ であった. 液状化地盤での 限界変位は, 液状化地盤中では埋設深さには関係なく管 路の管径に反比例している.

液状化実験および飽和砂・排水砂実験の抵抗力-変位 関係をそれぞれ最大上方地盤抵抗力と限界変位で除した 関係を，図一7に示している。なお，図中の記号は，表 -1に示される記号（実験ケース）と同様である.

液状化中・終了直後の地盤では, 抵抗力-変位関係の 勾配が排水砂の勾配より小さく，液状化中の勾配と液状 化終了直後の勾配はほぼ同じであった。しかし，飽和砂 においては排水砂よりも勾配が大きい傾向にあった．実 験結果を双曲線関数で近似した場合のそれぞれの関数形 は図中に示すようである.

図一7に示される最大抵抗力およ び限界変位で補正した抵抗力-変位 関係から，地盤ばね定数 $k$ は無次 元化最大抵抗力 $F_{m}$ を使って次式で 表わされる.

$$
k=\frac{F_{m}}{D \cdot L} \times \frac{1}{\alpha \cdot \delta_{V, \text { cri }} \cdot \pi}
$$

ここに， $\alpha$ :地盤ばね定数をバイリ ニア型で表示したときの無次元化す ベり限界変位係数（表一2）である.

図一8は, 排水砂, 飽和砂地盤の 実験結果および液状化地盤の実験結 果から式（2）を用いて算出した地 盤ばね定数の值と $H^{\prime} / D$ の関係を 示している. 図より, 地盤が硬く, 埋設深さが大きいほよ゙地盤ばね定数 は大きな值を示し, 液状化中の $\phi$ 


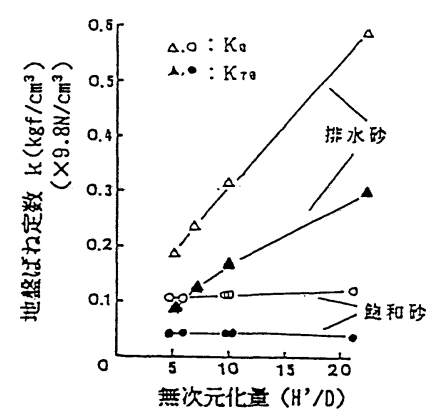

a) 排水碑・的和砧

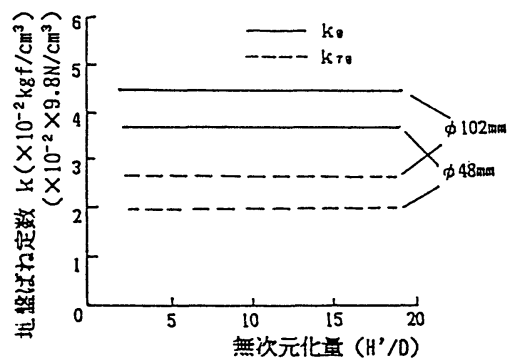

b) 液状化中・液状化直後

図一8 地盤ばね定数と $H^{\prime} / D$ との関係

表一2 地盤ばね算出のための係数

\begin{tabular}{|c|c|c|c|c|}
\hline 実敛名 & $\begin{array}{l}\text { 無 次 } \\
\text { 初期勾配 }\end{array}$ & $\begin{array}{l}\text { 完 化 } \\
70 \% \text { 配 }\end{array}$ & \begin{tabular}{|c|} 
位 $\alpha$ \\
$100 \%$ 勾配
\end{tabular} & $\delta \underset{\beta}{\delta \mathrm{v}, \mathrm{cri} / \mathrm{H}^{\prime}}$ \\
\hline 被状化中 & 0.43 & 0.715 & 1.00 & $\cdots \cdot$ \\
\hline 液状化直後 & 0.43 & 0.715 & 1.00 & $H^{\prime} / D>4,0.11$ \\
\hline 排水砂 & 0.29 & 0.577 & 1.00 & 0.03 \\
\hline 蚫和 砂 & 0.14 & 0.357 & 1.00 & 0.04 \\
\hline 乾燥砂 & 0.07 & 0.287 & 1.00 & 0.01 \\
\hline
\end{tabular}

表一3 地盤ばね定数值 $\left(H^{\prime}=1.2 \mathrm{~m}\right)$

\begin{tabular}{|c|c|c|c|c|c|c|}
\hline \multirow[t]{2}{*}{ 実稌名 } & \multicolumn{3}{|c|}{$\begin{array}{r}\text { 地盤ばね定数 }\left(\mathrm{kgf} / \mathrm{cm}^{3}\right) \\
\left(\times 9.8 \mathrm{~N} / \mathrm{cm}^{3}\right)\end{array}$} & \multicolumn{3}{|c|}{$\begin{array}{c}\text { すべり限界変位 } \\
(\mathrm{cm})\end{array}$} \\
\hline & 初 期 & $70 \%$ & $100 \%$ & 初 期 & $70 \%$ & $100 \%$ \\
\hline $\begin{array}{l}\text { 液状化中 } \\
(\phi 48 \mathrm{~mm})\end{array}$ & 0.037 & 0.020 & 0.013 & 2.6 & 4.8 & 7.3 \\
\hline $\begin{array}{l}\text { 液状化中 } \\
(\phi 102 \mathrm{~mm})\end{array}$ & 0.045 & 0.027 & 0.019 & 1.9 & 3.1 & 4.4 \\
\hline $\begin{array}{c}\text { 液状化直後 } \\
(\phi 48 \mathrm{~mm})\end{array}$ & 0.043 & 0.0109 & 0.0036 & 7.7 & 15.2 & 26.4 \\
\hline $\begin{array}{r}\text { 液状化直後 } \\
(\phi 102 \mathrm{~mm}) \\
\end{array}$ & 0.040 & 0.0145 & 0.0074 & 5.7 & 9.4 & 13.2 \\
\hline 排水砂 & 0.36 & 0.18 & 0.10 & 1.0 & 2.1 & 3.6 \\
\hline 飽和砂 & 0.11 & 0.043 & 0.015 & 0.5 & 1.4 & 4.8 \\
\hline
\end{tabular}

$102 \mathrm{~mm}$ での地盤ばね定数は $\phi 48 \mathrm{~mm}$ よりも大きな值を 示している.

表一 3 に, $H^{\prime}=1.2 \mathrm{~m}$ と仮定した場合の $\phi 48 \mathrm{~mm}$ と $\phi$ $102 \mathrm{~mm}$ の場合におけるばね定数と, 抵抗力-変位関係 をバイリニア型としたときのすべり限界変位量を示して いる. 排水砂・飽和砂でのばね定数と限界変位は, 以下 に示す田邊 ${ }^{101}$ が用いている式 $(3),(4)$ から算出した.

$$
\begin{aligned}
& \frac{F_{m}}{\gamma \cdot H^{\prime} \cdot D \cdot L}=1-\frac{\pi \cdot D}{8 \cdot H^{\prime}}+K \cdot \tan \phi \cdot \frac{H^{\prime}}{D} \\
& k=\left(1-\frac{\pi \cdot D}{8 \cdot H^{\prime}}+K \cdot \tan \phi \cdot \frac{H^{\prime}}{D}\right) \cdot \frac{\gamma}{\alpha \cdot \beta \cdot \pi}
\end{aligned}
$$

ただし， $\gamma$ : 土の単位体積重量 $\left(2.0 \mathrm{gf} / \mathrm{cm}^{3}\right), \phi:$ 砂の せん断抵抗角, $\beta=\delta_{v, \mathrm{cri}} / H^{\prime}, K=\pi \cdot k \cdot D$, 他の諸量は 前出と同じである.

ここで，液状化中・終了直後の最大抵抗力が既知であ れば,地盤ばね定数から限界変位を求めることができる. したがって, 液状化中の地盤ばね定数とともに最大抵抗 力の検討が重要な課題となる.

表一3から，液状化時の地盤沈下による地盤ばね定数 は普通地盤のばね定数（ $k=0.6 \mathrm{kgf} / \mathrm{cm}^{3} \quad(5.88$ $\left.\left.\mathrm{kN} / \mathrm{cm}^{3}\right)\right)^{8)}$ に対し，液状化地盤で $\phi 48 \mathrm{~mm}$ の場合で 1/50 に， $\phi 102 \mathrm{~mm}$ の場合では $1 / 32$ に低下する.また， 飽和砂では $1 / 40$, 排水砂では $1 / 6$ に低下することが知 られる.ここで, 液状化地盤において管路の管径が小さ い方が地盤ばね定数が小さくなっているのは最大抵抗力 が小さいにもかかわらず,限界変位が大きいからである.

\section{3. 二重砂槽による地中管路の沈下挙動実験}

表一3から知られるように排水砂地盤での地盤ばね定 数は大きく，液状化終了後の沈下を受ける管路への影響 が大きいことが予想される，そこで，弾性地盤上のはり 理論によって管路の耐震設計を行うときに，表一3に示 される初期， $70 \% ， 100 \%$ の勾配のどの地盤ばね定数 が設計へ適用されるかを検討するために，以下に示す実 験を実施した。

\section{(1) 実 験 概 要}

図一9に実験の概要を示している．管路周用の土層が 飽和砂あるいは排水砂状態にあることと均一に沈下する ことを保つために，二重砂槽を使用している．二重砂槽 の内槽と外槽の側壁の間には 8 つローラが設置されて おり，これによって内槽が垂直沈下し，2つの槽壁の摩 擦を減少している. 内外土槽の底部の間に $10 \mathrm{~cm}$ の砕 石層, $20 \mathrm{~cm}$ の硫安層, $15 \mathrm{~cm}$ の砂層を順番に敷いてい る. 内部土槽内の地盤に管路が敷設し，一端は固定，他 端は自由で片持ち状態になっている。砕石層に注水する ことにより硫安が溶けて内部土槽が沈下し, 地盤と管路 に相対変位を生ぜしめ, その折の管路挙動を調べる。な お, 飽和砂地盤亡排水砂地盤の作成は前述の上方抵抗実 験と同じ方法を使っている.

実験にはVP $\phi 20 \mathrm{~mm}, \mathrm{VU} \phi 40 \mathrm{~mm}$ の 2 種類の管路 を使用した，管路諸元は表一4に示している，地盤の沈 下量は地盤表面に設置している変位計Dで，管体のひず みはひずみケージ $\mathrm{C}_{1} \sim \mathrm{C}_{9}$ で計測している. 

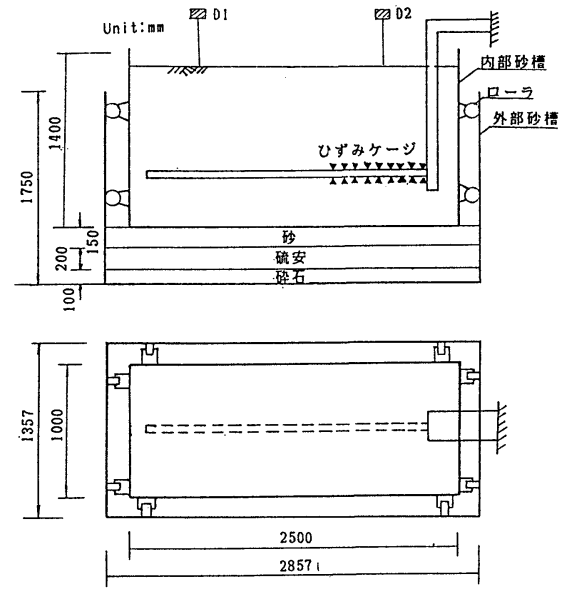

図一9 実験装置および二重砂槽概要

表一4 供試管諸元

\begin{tabular}{|c|c|c|}
\hline & VP $\phi 20$ & V U $\phi 40$ \\
\hline $\begin{array}{c}\text { 外 径 } \\
(\mathrm{mm})\end{array}$ & 26 & 48 \\
\hline $\begin{array}{c}\text { 内 径 } \\
(\mathrm{mm})\end{array}$ & 20 & 44 \\
\hline $\begin{array}{c}\text { 弾性係数 } \\
(\mathrm{kgf} / \mathrm{cm})\end{array}$ & \multicolumn{2}{|c|}{27000} \\
\hline
\end{tabular}

\section{（2）実験 結 果}

図一10 は実験結果の例であり，図中の黒点は異なる 管種，埋設深さ，地盤沈下量に対する管路の曲げ応力分 布である. 各ケースとも固定端付近で応力が最大となり， 最小応力の発生位置は沈下量の増加に伴って固定端から 離れていき，その距離は地盤が軟らかいほど，また，管 路の剛性が高くなるほど大きくなる傾向にある.図一11 は沈下量と応力の関係を示している. 図から知られるよ

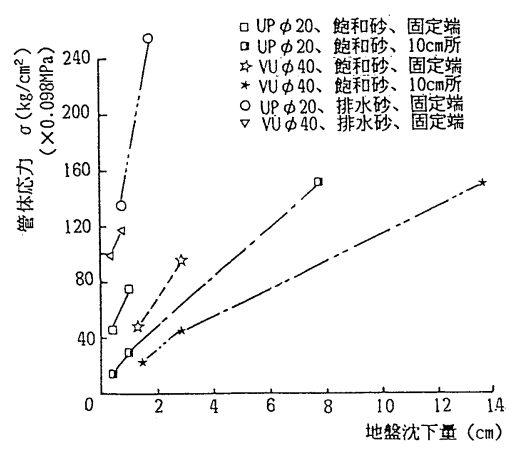

図一11 地盤沈下量と管路応力の関係

うに同じ地盤沈下量で排水砂地盤沈下の場合の管路応力 およびその傾きは飽和砂地盤の場合よりはるかに大き い.さらに，小管径の $\phi 20 \mathrm{~mm} \mathrm{VP}$ 管路応力は $\phi 40$ $\mathrm{mm}$ VU 管路より大きい. また，地盤沈下量が大きくな るにつれて管路応力-地盤沈下量の傾きが小さくなって いるのは前述の実験から知られるように地盤抵抗力の非 線形特性によるものである.

\section{4. 管路沈下挙動シミュレーション}

\section{（1）解析手法}

実験結果を検討するために，ERAUL (Earthquake Responses Analysis of Underground Lifelines) ${ }^{14)} フ^{\circ} \square$ グラムを用いた，ERAUL は弾性床上のはり理論をも とに伝達マトリックス法を用いて解析している. また， 地盤および継手の非線形性は荷重増分法を用いて考慮で きるようになっている.

解析に用いた管路モデルは，図一12に，またその特 性値に関しては表一4にすでに 示してある.バイリニア型の地

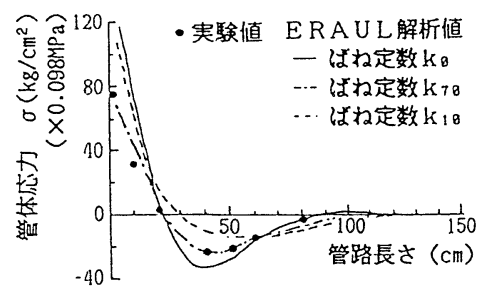

a) 绝和秒、沈下里 $1.1 \mathrm{~cm} 、 U P \phi 20 、 土$ 被り $53.5 \mathrm{~cm}$

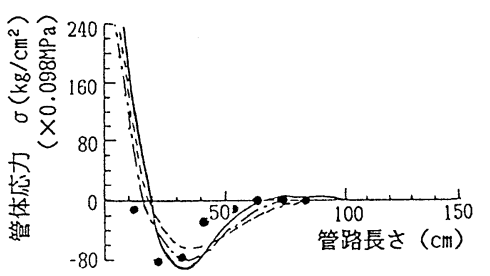

c）排水砂、沈下重 $1.8 \mathrm{~cm} 、$ UP $\phi 20 、 土$ 被り $36.0 \mathrm{~cm}$

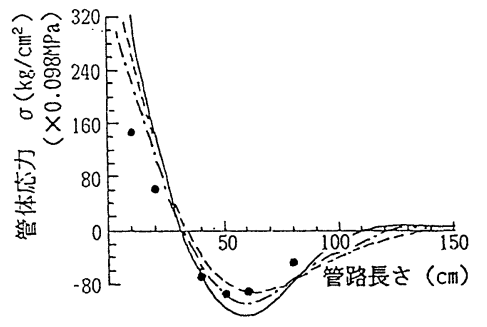

b) 飽和砂、沈下重 $7.8 \mathrm{~cm} 、 U P \phi 20 、 土$ 被り $53.5 \mathrm{~cm}$

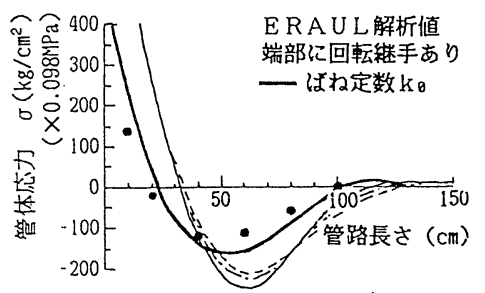

d）排水砂、沈下里 $8.2 \mathrm{~cm} 、 U V \phi 40 、 土$ 土被り $41.5 \mathrm{~cm}$

\section{(3)，(4) で与えた.}

(2) 数值シミュレーション 結果および検討

図一10の実・破線は各ケ一 スの数值解析結果による管体曲 げ応力分布である. 沈下量が小 さい段階では，排水砂地盤では 初期勾配 $\left(K_{0}\right)$ を用いた解析結

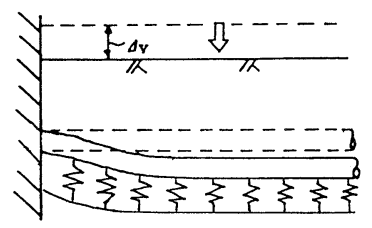

図一12 沈下挙動解析用管路モデル 
果に，飽和砂地盤では $70 \%$ 勾配 $\left(K_{70}\right)$ を用いた解析結 果によく一致している(図-10a),c)).しかし, 沈下 が進行するにつれて次第に実験值が計算值よりも小さく なっていくことがわかる(図-10b), d)).これは管固 定部の緩みが原因と考えられる．固定端の緩みを考慮し て計算した結果の例は図一10d）に示しているが，実験 結果とほぼ一致している。

実験結果と計算結果の比較によって液状化沈下に対す る地盤ばね定数としては, 排水砂地盤では初期勾配 $\left(K_{0}\right)$, 飽和砂地盤では $70 \%$ 勾配 $\left(K_{70}\right)$ を用いることが妥当で あると考えられる。

\section{5. 液状化沈下を受ける地中管路設計式および 等価地盤ばね定数の推定}

前述実験から得た地盤ばね定数を用いて，ERAUL プログラムで液状化沈下を受ける管路の挙動がよく把握 できることが知られたが，バイリニア型の非線形地盤ば ね定数であるので，実際設計時に異なる管路・埋設条件 について計算しなければならないから，時間，経済性の 面で問題がある。そこで，液状化沈下実験のデー夕から 弾性地盤上のはり理論によって統一的に液状化沈下挙動 を取り扱い，設計等価地盤ばね定数および設計式を求め る必要がある.

a) 液状化沈下を受ける管路設計式

液状化沈下による管路の被害は管路とマンホールなど の構造物の接合部で多発している。 そこで，液状化沈下 に対する埋設管路の設計式の誘導にあたり，図一13に 示すように基礎の堅固なマンホールに取り付けられた無 継手管路，有継手管路 (2 種類) の3つの形態にモデル 化して, 弾性地盤上のはり理論を用いて, 次式のように 管体曲げ最大応力の算定式を誘導した ${ }^{91}$.
Case-1

$$
\sigma_{\max }=E \cdot \delta \cdot \beta^{2} \cdot D \quad(x=0)
$$

Case-2, Case-3

$$
\sigma_{\max }=E \cdot \delta \cdot \beta^{2} \cdot D \frac{A_{1}}{A_{2}} \quad(x=0)
$$

ここに, $E$ : ヤング率, $D$ : 管路の外径, $A_{1}=e^{\beta L}(2+$ $\left.B_{R} \cdot \beta\right)+e^{-\beta L} B_{R} \cdot \beta\{1-2 \cdot \cos \beta L(\cos \beta L-\sin \beta L)\}, \quad A_{2}$ $=e^{\beta L}\left(2+B_{R} \cdot \beta\right)+e^{-\beta L} B_{R} \cdot \beta\{1+2 \cdot \cos \beta L(\cos \beta L-\sin$ $\beta L)\}, B_{R}=E I / K_{R}, K_{R}$ : 継手の回転剛性，である.

b) 液状化沈下等価地盤ば放定数の推定

まず，埋設深さを表一 5 のように数段階に区分し，各 区分ごとに等価地盤ばね定数，限界変位を式（3)，(4) を用いて算出する. 次に，表一 5 の数值を使って ERAUL プログラムで管路の沈下挙動を解析する. 本 解析は地盤ばねの軟化を考慮した非線形解析である。図 -14の実線は排水砂, 飽和砂地盤の場合の管路最大応 力と地盤沈下量の関係についての ERAUL 解析結果の 例である。

次いで，沈下等価地盤ばね定数の推定にあたり，式

\begin{tabular}{|c|c|c|c|c|c|}
\hline \multicolumn{2}{|c|}{ 区分 } & $\begin{array}{l}\text { 埋投深さ } \\
\text { (II) }\end{array}$ & $\begin{array}{c}\text { 平均埋投深さ } \\
\text { (II) }\end{array}$ & 地盤ばれ & $\begin{array}{l}\text { 限界变位 } \\
\delta(\mathrm{cm})\end{array}$ \\
\hline \multirow{3}{*}{ 排 } & 1 & $0.5 \leqq H<1.0$ & 0.75 & 0.169 & 0.65 \\
\hline & 2 & $1.0 \leq H<1.5$ & 1.25 & 0.244 & 1.09 \\
\hline & 3 & $1.5 \leq H<2.0$ & 1.75 & 0.318 & 1.52 \\
\hline \multirow{3}{*}{ 水 } & 4 & $2.0 \leqq H<2.5$ & 2.25 & 0.391 & 1.96 \\
\hline & 5 & $2.5 \leq H<3.0$ & 2.75 & 0.464 & 2.39 \\
\hline & 6 & $3.0 \leq H<3.5$ & 3.25 & 0.537 & 2.83 \\
\hline \multirow{3}{*}{ 碀. } & 7 & $3.5 \leqq H<4.0$ & 3.75 & 0.610 & 3.26 \\
\hline & 8 & $4.0 \leq H<4.5$ & 4.25 & 0.683 & 3.70 \\
\hline & 9 & $4.5 \leq H<5.0$ & 4.75 & 0.755 & 4.13 \\
\hline 鲜 & 10 & $0.5 \leqq H<1.5$ & 1.00 & 0.042 & 1.43 \\
\hline 和 & 11 & $1.5 \leq H<3.0$ & 2.25 & 0.043 & 3.21 \\
\hline 琀 & 12 & $3.0 \leq H<5.0$ & 4.00 & 0.044 & 5.71 \\
\hline
\end{tabular}

表一5 埋設深さごとの地盤のばね定数および限界変位
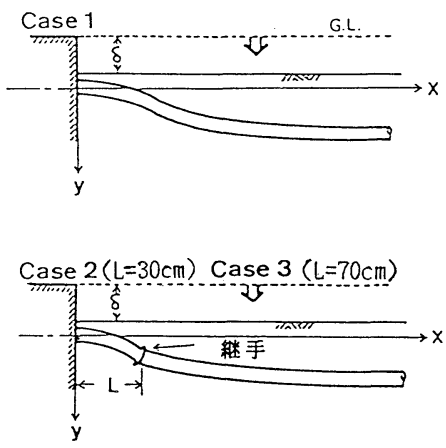

図一13等価地盤ばね定数を推定する ための解析モデル

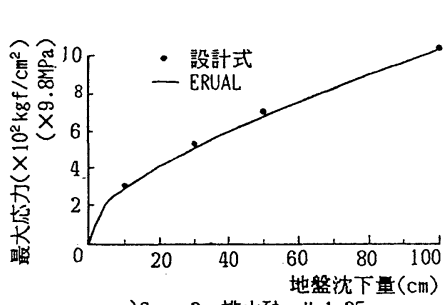

a)Caes 2 排水砂 $H=1.25 \mathrm{~m}$

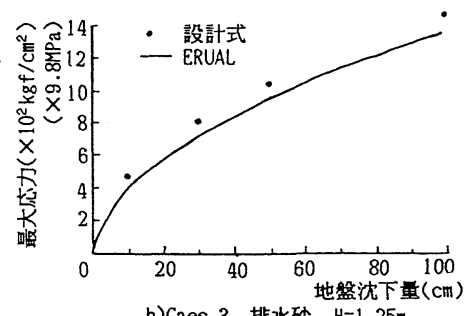

b)Caes 3 排水砂 $\mathrm{H}=1.25 \mathrm{~m}$

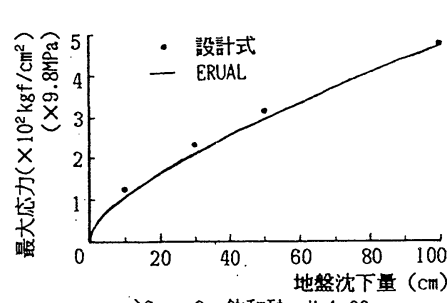

c)Caes 3 飽和砂 $\mathrm{H}=1.00 \mathrm{~m}$

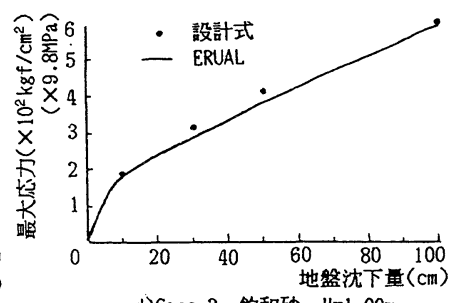

d)Caes 3 飽和砂 $\mathrm{H}=1.00 \mathrm{~m}$

図一14 ERAUL・設計式による管路最大ひずみと地盤沈下量の関係 

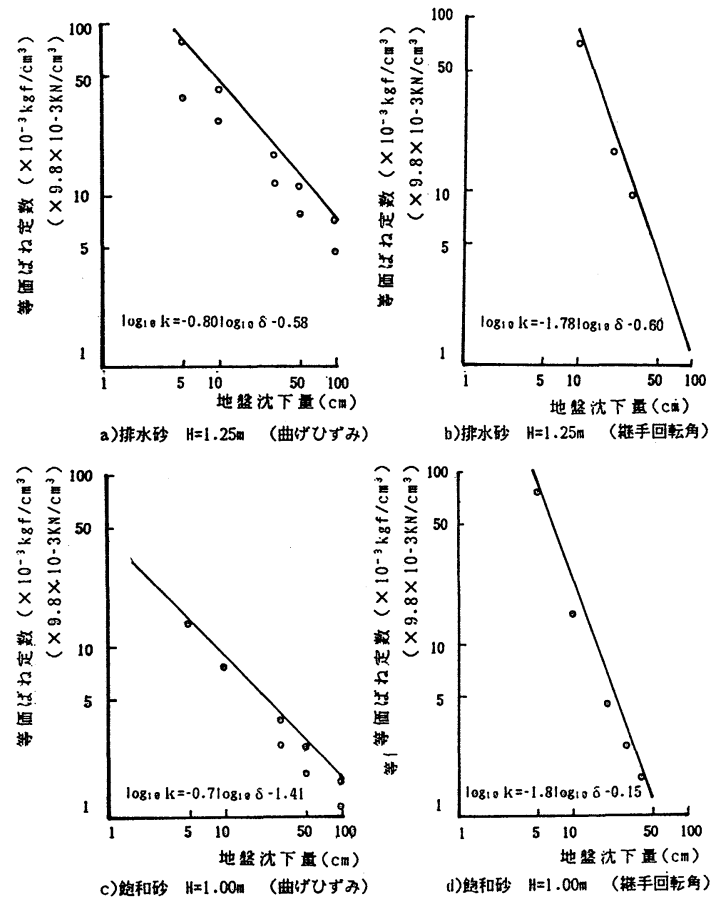

図一15等価地盤ばね定数と地盤沈下量の関係

表一6 埋設深さごとの等価ばね定数の諸係数 （曲げひずみ計算用）

\begin{tabular}{|c|c|c|c|c|}
\hline \multicolumn{2}{|c|}{ 区分 } & $\begin{array}{l}\text { 平均埋喤 } \\
\text { 深さ }(\mathrm{m})\end{array}$ & A & B \\
\hline \multirow{4}{*}{ 排 } & 1 & 0.75 & -0.727 & -1.015 \\
\hline & 2. & 1.25 & -0.799 & -0.580 \\
\hline & 3 & 1.75 & -0.837 & -0.318 \\
\hline & 4 & 2.25 & -0.827 & -0.173 \\
\hline \multirow[t]{3}{*}{ 水 } & 5 & 2.75 & -0.850 & -0.011 \\
\hline & 6 & 3.25 & -0.799 & 0.022 \\
\hline & 7 & 3.75 & -0.778 & 0.082 \\
\hline \multirow[t]{2}{*}{ 杪 } & 8 & 4.25 & -0.769 & 0.139 \\
\hline & 9 & 4.75 & $=0.699$ & 0.120 \\
\hline 飽 & 10 & 1.00 & -0.699 & -1.409 \\
\hline 和 & 11 & 2.25 & -0.709 & -1.100 \\
\hline 砂 & 12 & 7.00 & -0.637 & -1.027 \\
\hline
\end{tabular}

（継手回転角計算用）

注: $\log _{10} \mathrm{k}=\mathrm{A} \cdot \log _{10} \delta+\mathrm{B}$

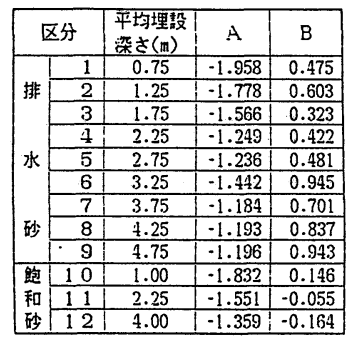

$\mathrm{k}$ :ばね定数、 $\delta$ :地盤沈下量 $(\mathrm{cm})$

（5)，（6）で示した設計式に地盤沈下量を代入し，地 盤ばね定数を逐次変化させながら，ERAUL で計算し た管体最大曲げひずみおよび継手回転角と一致する沈下 量ごよの等価地盤ばね定数を求めた．その值を両対数グ ラフ上にプロットして，等価ば称定数と地盤沈下量の関 係を求めると図一15 が得られる. 図一15 は排水砂・埋 設深さ $1.25 \mathrm{~m}$ と飽和砂埋設深さ $1.0 \mathrm{~m}$ の計算例であ る.さらに, 排水砂, 飽和砂の場合に各深さごとの計算 結果を表一6に示している. 図一15より, 実験デー夕か ら推定された地盤ばね定数は, 沈下量の小さい段階では ばらついているが，沈下量が大きくなるにつれて右下が りの一定の傾向を示している．式（5)，（6）に用いる 等価地盤ば权定数には安全側評価を与える上界線（図一 15 中の実線）が考えられる. c) 管路設計式, ERAUL 解析, 実験結果との比較 等価ばね定数と設計式の有効性を検討するために, 最 大曲げひずみに関する設計式に，表一6で与えられる沈 下等価地盤ばね定数および地盤沈下量を代入することに より ERAUL 計算結果と比較する. 図一14にその比較 例を示す．図から知られるように等価地盤ばね定数を用 いた設計式による最大曲げひずみは ERAUL プログラ ムの解析結果とよく一致しており, 若干, 安全側の評価 を与えていることがわかる.

\section{6. おわりに}

本文では液状化地盤の沈下を受ける管路の挙動および その設計に着目して, 以下の事項を検討していくつかの 新たな知見を得た。

（1）室内模型地盤内の管路の上方抵抗実験によって 液状化地盤, 飽和砂地盤および排水砂地盤の抵抗力-変 位関係, さらに, 地盤ばね定数および限界変位を求めた。 飽和砂地盤, 排水砂地盤の抵抗力, 地盤ば社定数は埋設 深さが深くなるほど大きくなるが, 液状化地盤では, 地 盤の抵抗力, 地盤ばね定数は埋設深さと関係なくほぼ一 定值であり, 粘性流体と仮定した場合の抵抗力とよく一 致する.

（2）液状化時の地盤沈下による地盤ばね定数は普通 地盤のば社定数 $\left(k=0.6 \mathrm{kgf} / \mathrm{cm}^{3}\left(5.88 \mathrm{kN} / \mathrm{cm}^{3}\right)\right)^{8)}$ に 対し, 液状化地盤で $\phi 48 \mathrm{~mm}$ の場合で約 $1 / 50$ に, $\phi$ $102 \mathrm{~mm}$ の場合では約 $1 / 32$ に低下する. また, 飽和砂 では約 $1 / 40$ ，排水砂では約 $1 / 6$ に低下する.

（3）二重沈下土層を開発して, 硫安の水溶性を利用 した飽和砂, 排水砂地盤の沈下実験から, 管路の挙動を 調べた。その結果, 地盤ばね定数として上方抵抗実験の 排水砂初期勾配あるいは飽和砂 $70 \%$ 勾配を用いて沈下 解析を行うと管路挙動をよく説明できることが知られ た。

（4）弾性地盤上のはり理論計算モデルによって管路 最大ひずみの算定式を誘導し, 本式に用いる等価地盤ば ね定数を ERAULによる非線形解析と沈下実験結果の 比較により算出した。さらに，その適用性を調べた。

\section{参 考 文 献}

1）田邊揮司良・高田至郎：ライフライン解析のための地震 時地盤沈下量の推定, 土木学会論文集, No. 392/ I -9, pp. $377 \sim 384,1988$ 年 4 月.

2）高田至郎・田邊揮司良：1983 年日本海中部地震における 地中ライフライン被害, 建設工学研究所報告, No. 26, pp. 93 112, 1984 年 12 月.

3）高田至郎・田邊揮司良ほか：液状化を受ける通信用管路 の挙動解析々地震対策, 建設工学研究所報告, No. 26, pp. 113 137, 1984 年 12 月. 
4）片田敏行・伯野元彦：液状化過程における地中構造物の 動的挙動に関する実験的研究, 土木学会論文報告集, No. 396, pp. 1 10, 1981 年 2 月.

5）北浦 勝・宮島昌克：液状化過程における地中埋設管の ひずみ特性に関する実験的研究, 土木学会論文報告集, No. 323, pp. 43 53, 1982 年 7 月.

6) 高田至郎・山部泰男 : 沈下土槽による埋設管路の大変形 実験とその解析, 土木学会論文報告集, No. 323, pp. 55 ～65, 1982 年 7 月.

7）大石 博：地盤沈下を受ける埋設管路の挙動に関する二, 三の考察, 土木学会論文報告集, No. 356, pp. 379 386, 1985 年 4 月.

8）たとえば，日本ガス協会：ガス導管耐震設計指針, 1982 年 3 月。

9）田邊揮司良・高田至郎：地盤沈下を受ける地中管路設計 式と適用, 土木学会論文集, No. 374／I -6, pp. 593～602, 1986 年 10 月.
10) 田邊揮司良：地震時地盤変状を受ける地中管路の耐震性 評価と設計法に関する基礎的研究, 神戸大学博士論文, 1988 年 1 月.

11) Trautmann, C.H. and O'Rourke, T.D. : Lateral Force-Displacement Response of Buried Pipe, J. Geo. Eng., ASCE, Vol. 111, No. 9, pp. 1077 1092, 1984.9.

12）永井淳一：液状化地盤中にある構造物の動的応答解析, 神戸大学修士論文, 1987 年 2 月.

13) Lagerstrom, P.A. and Chang, I.D. : Flow at Iow Reynolds Numbers, Flugge, W., Editor, Handbook of Eng. Mechanics, McGraw-Hill, New York, pp.81.1 81. 30 .

14）高田至郎・高橋俊二・山部泰男：硬質塩化ビニル管の地 震時挙動シミュレーション, 水道協会雑誌, No. 547, pp. $27 \sim 39$, 1980. 4 .

(1989.12.11 • 受付) 